\title{
SMYD3 wt Allele
}

National Cancer Institute

\section{Source}

National Cancer Institute. SMYD3 wt Allele. NCI Thesaurus. Code C53124.

Human SMYD3 wild-type allele is located in the vicinity of $1 \mathrm{q} 44$ and is approximately 758 $\mathrm{kb}$ in length. This allele, which encodes SET and MYND domain-containing protein 3, plays a role in both the methylation of histones and the regulation of transcription by RNA polymerase II. 